\title{
Thalamohippocampal atrophy in focal epilepsy of unknown cause at the time of diagnosis
}

\author{
${ }^{*}$ Corresponding author \\ Dr Simon Keller \\ Clinical Sciences Centre \\ Aintree University Hospital \\ Lower Lane \\ Liverpool \\ L9 7LJ \\ simon.keller@liv.ac.uk
}

Nicola J. Leek ${ }^{1}$, Barbara A. K. Kreilkamp ${ }^{1,2}$, Mollie Neason ${ }^{1}$ Christophe de Bezenac ${ }^{1}$, Besa Ziso², Samia Elkommos ${ }^{3}$, Kumar Das², Anthony G. Marson ${ }^{1,2}$, Simon S. Keller ${ }^{1,2^{*}}$

1Department of Pharmacology and Therapeutics, Institute of Systems, Molecular and Integrative Biology, University of Liverpool, UK ${ }^{2}$ The Walton Centre NHS Foundation Trust, Liverpool, UK ${ }^{3}$ St George's University Hospitals NHS Foundation Trust, London, UK

Keywords: Newly diagnosed epilepsy, focal epilepsy, thalamus, hippocampus, treatment outcome 
medRxiv preprint doi: https://doi.org/10.1101/2020.07.24.20159368; this version posted July 25, 2020. The copyright holder for this preprint (which was not certified by peer review) is the author/funder, who has granted medRxiv a license to display the preprint in perpetuity.

\begin{abstract}
Background: Patients with chronic focal epilepsy may have atrophy of brain structures important for the generation and maintenance of seizures. However, little research has been conducted in patients with newly diagnosed focal epilepsy (NDfE), despite it being a crucial point in time for understanding the underlying biology of the disorder. We aimed to determine whether patients with NDfE show evidence of volumetric abnormalities of subcortical structures.
\end{abstract}

Methods: Eighty-two patients with NDfE and 40 healthy controls underwent MRI scanning using a standard clinical protocol. Volume estimation of the left and right hippocampus, thalamus, caudate nucleus, putamen and cerebral hemisphere was performed for all participants and normalised to whole brain volume. Volumes lower than two standard deviations below the control mean were considered abnormal. Volumes were analysed with respect to patient clinical characteristics, including treatment outcome 12 months after diagnosis.

Results: Volume of the left hippocampus $\left(P_{(\text {FDR-corr })}=0.04\right)$ and left $\left(P_{(\text {FDR-corr })}=0.002\right)$ and right $\left(P_{(\mathrm{FDR}-\mathrm{corr})}=0.04\right)$ thalamus were significantly smaller in patients relative to controls. Relative to the normal volume limits in controls, $11 \%$ individual patients had left hippocampal atrophy, $17 \%$ had left thalamic atrophy and $9 \%$ had right thalamic atrophy. We did not find evidence of a relationship between volumes and future seizure control or with other clinical characteristics of epilepsy.

Conclusions: Volumetric abnormalities of structures known to be important for the generation and maintenance of focal seizures are established at the time of epilepsy diagnosis and are not necessarily a result of the chronicity of the disorder. 
medRxiv preprint doi: https://doi.org/10.1101/2020.07.24.20159368; this version posted July 25, 2020. The copyright holder for this preprint (which was not certified by peer review) is the author/funder, who has granted medRxiv a license to display the preprint in perpetuity.

\section{Introduction}

There is a wealth of evidence indicating that people with refractory focal epilepsy have quantitative structural brain abnormalities on magnetic resonance imaging (MRI). Atrophy of temporal lobe structures is frequently identified in patients with temporal lobe epilepsy (TLE), including the hippocampus, entorhinal cortex, perirhinal cortex and amygdala, preferentially ipsilateral to the side of seizure onset [1]. Extrahippocampal subcortical atrophy is also commonly reported, including the thalamus and striatum in both cerebral hemispheres ${ }^{[1,2]}$. In TLE seizures are primarily generated in the hippocampus; in vitro electrophysiology of resected hippocampal tissue from refractory patients has shown the dentate gyrus to be the most susceptible region to the generation of epileptiform activity [3]. Intracerebral recordings of electroencephalography (EEG) activity in patients with refractory focal epilepsy exhibit an increase of synchrony between the thalamus and temporal lobe structures during seizures ${ }^{[4]}$. Furthermore, an increase in neuronal firing rate in the caudate nucleus and putamen has been observed during prefrontal seizures in an animal model of epilepsy ${ }^{[5]}$. Therefore, there is a well-established link between subcortical atrophy and brain seizure activity in patients with chronic focal epilepsy. However, it remains unclear whether subcortical atrophy in focal epilepsy is pre-existing, present at the time of diagnosis as a consequence of epileptogenic processes, or the result of the chronicity of longstanding epilepsy and antiepileptic drug (AED) treatment. It is therefore important to determine whether brain abnormalities are already established in the early stages of epilepsy.

Despite that epileptogenesis begins prior to the onset of a first seizure ${ }^{[6]}$, the earliest reliable time point of investigation of human epilepsy in prospective studies is at the 
medRxiv preprint doi: https://doi.org/10.1101/2020.07.24.20159368; this version posted July 25, 2020. The copyright holder for this preprint (which was not certified by peer review) is the author/funder, who has granted medRxiv a license to display the preprint in perpetuity.

It is made available under a CC-BY-ND 4.0 International license.

point of diagnosis. Neuroimaging studies of patients with newly diagnosed epilepsy (NDE) have the potential to provide important information about the nature of brain abnormalities by separating pre-existing or novel abnormalities and longstanding changes originating from recurrent seizures and chronic use of AEDs ${ }^{[7]}$. The identification of quantitative imaging abnormalities at diagnosis may provide new insights into biomarkers of pharmacoresistance and cognitive comorbidities [8, 9]. Approximately $60 \%$ of patients with NDE will achieve seizure control, $\sim 25 \%$ will develop pharmacoresistant epilepsy and the remainder will fluctuate between remission and relapse ${ }^{[10]}$. To date, markers of pharmacoresistance in patients with NDE have been limited to reports in epidemiological studies and clinical trials, and suggest, for example, that gender, treatment history, age, and time between first seizure and diagnosis may be related to pharmacoresistance ${ }^{[11,12]}$. Determining the relationship between quantitative brain imaging at diagnosis and AED treatment outcome is an important research endeavour ${ }^{[8]}$. Additionally, over $50 \%$ of patients with NDE have been found to show impairment in at least one cognitive domain [13]. Quantitative imaging studies may further contribute to the understanding of cognitive problems which may be present at point of diagnosis.

There are few quantitative neuroimaging studies in patients with newly diagnosed focal epilepsy (NDfE). Although a small number of studies have identified localised brain atrophy in patients with NDfE, findings are inconsistent. One study revealed hippocampal atrophy in patients with NDfE relative to controls ${ }^{[14]}$, whilst others have found no difference in hippocampal volume between these groups ${ }^{[15,16]}$. Inconsistent findings have been reported on structural changes in the cerebellum in patients with NDfE $[16,17]$. In a small-scale study using voxel-based morphometry, we were unable 
medRxiv preprint doi: https://doi.org/10.1101/2020.07.24.20159368; this version posted July 25, 2020. The copyright holder for this preprint (which was not certified by peer review) is the author/funder, who has granted medRxiv a license to display the preprint in perpetuity. It is made available under a CC-BY-ND 4.0 International license.

to identify morphometric alterations of subcortical or cortical regions in patients with NDfE compared to controls ${ }^{[18]}$. Although, to our knowledge, no studies have identified thalamic atrophy in adult NDfE, a recent study reported thalamic atrophy in drug naïve patients with new-onset genetic generalised epilepsy (GGE) ${ }^{[19]}$.

There were two primary objectives of the present study. Firstly, we sought to determine whether atrophy of the hippocampus, thalamus, caudate nucleus, putamen and cerebral hemisphere is present at the time of diagnosis of focal epilepsy with unknown cause relative to healthy controls. Secondly, we aimed to explore whether volumetric changes of these structures are related to various clinical characteristics of the disorder including treatment outcome at 6 and 12 months after diagnosis. 
medRxiv preprint doi: https://doi.org/10.1101/2020.07.24.20159368; this version posted July 25, 2020. The copyright holder for this preprint

\section{Methods}

\section{Participants}

We identified patients with archived MRI, acquired according to a clinical epilepsy protocol, within 12 months of diagnosis of focal epilepsy of unknown cause and scanned on a 3 T GE Discovery MRI system at the Walton Centre NHS Foundation Trust, Liverpool, UK since 2015. At initial screening, 140 patients with likely NDfE and corresponding MRI for analysis were retrieved. More detailed assessment of patient clinical histories and MRI resulted in the exclusion of 58 patients due to one of the following factors: (1) first seizure with no diagnosis of epilepsy, (2) probable idiopathic generalised epilepsy, (3) symptomatic seizures (e.g. tumour, infection), (4) presence of epileptogenic lesion (e.g. focal cortical dysplasia, hippocampal sclerosis), or (5) unusable or unavailable MRI data for analysis. This resulted in 82 patients with NDfE of unknown cause with corresponding MRI data for image analysis (Table 1). All patients were diagnosed by consultant neurologists at the Walton Centre NHS Foundation Trust. All images were reported non-lesional by a neuroradiologist with expertise in the assessment of MRI for epileptogenic lesions. All patients had no history of learning disability. 
medRxiv preprint doi: https://doi.org/10.1101/2020.07.24.20159368; this version posted July 25 , 2020. The copyright holder for this preprint (which was not certified by peer review) is the author/funder, who has granted medRxiv a license to display the preprint in perpetuity.

It is made available under a CC-BY-ND 4.0 International license .

\begin{tabular}{lll}
\hline Clinical variable & Patients & Controls \\
\hline$n$ & 82 & 40 \\
Age at diagnosis / MRI & $38.04(10.8)$ & $32.50(8.9)$ \\
Sex & $50 \mathrm{M} / 32 \mathrm{~F}^{*}$ & $16 \mathrm{M} / 24 \mathrm{~F}^{*}$ \\
FAS & $35 / 82(42.7 \%)$ & - \\
FIAS & $47 / 82(57.3 \%)$ & - \\
FBTCS & $72 / 82(87.8 \%)$ & - \\
Normal EEG & $39 / 51(76.5 \%)$ & - \\
Abnormal EEG & $12 / 51(23.5 \%)$ & - \\
Seizure free - 6 months & $23 / 58(39.7 \%)$ & - \\
Seizure free - 12 months & $24 / 48(50 \%)$ & - \\
\hline
\end{tabular}

Table 1. Demographic and clinical data. Mean age at diagnosis / MRI is presented with standard deviation. MRI, magnetic resonance imaging; FAS, focal aware seizures; FIAS, focal impaired awareness seizures; FBTCS, focal to bilateral tonic-clonic seizures; EEG, electroencephalography. *Significantly different $\left(x_{2}=4.72, P=0.03\right)$.

Additional clinical data were obtained by searching through hospital electronic records. We obtained age at diagnosis and seizure type (focal aware seizures [FAS], focal impaired awareness seizures [FIAS] and focal to bilateral tonic-clonic seizures [FBTCS]) for patients. Fifty-one (62.2\%) had undergone EEG and we recorded whether inter-ictal abnormalities were captured. Seizure status at 6 and 12 months after diagnosis, hereon referred to as seizure outcome, was obtained for 58 patients at 6 months and 48 patients at 12 months.

For comparison with patients, we used imaging data from a cohort of 40 healthy adult controls that were scanned as part of a different study ${ }^{[20]}$ but who had the equivalent MRI scans for comparative analysis (Table 1). There was no significant difference between the age of patients (when diagnosed) and controls (at time of MRI) $(t=2.8$, $P=0.13)$. However, there was a significant sex difference between patients and controls $\left(x^{2}=4.72, P=0.03\right)$. The North West - Liverpool research ethics committee approved this study (14/NW/0332). 
medRxiv preprint doi: https://doi.org/10.1101/2020.07.24.20159368; this version posted July 25,2020 . The copyright holder for this preprint (which was not certified by peer review) is the author/funder, who has granted medRxiv a license to display the preprint in perpetuity.

\section{MRI acquisition}

The standard 3 Tesla MRI protocol for patients with a new presentation of seizures at our centre included a high in-plane resolution T1-weighted fluid attenuated inversion recovery (FLAIR) MRI acquisition of the whole brain (TE $1.5 \mathrm{~ms}$, TR $2500 \mathrm{~ms}$, flip angle $111^{\circ}$, voxel size $0.4 \mathrm{~mm} \times 0.4 \mathrm{~mm}$, slice thickness $3.0 \mathrm{~mm}$, FOV $220 \mathrm{~mm}$, matrix size $320 \times 384)$. This sequence was used for analysis in the present study. Other sequences acquired for diagnostic purposes but not used for analysis included axial T2-weighted and coronal T2-FLAIR scans.

\section{MRI analysis}

Given the slice thickness of the T1-weighted FLAIR images, we were unable to reliably apply automated image analysis tools to extract subcortical and hemispheric volume. We therefore used rigorous manual techniques to estimate the volume of subcortical and hemispheric structures. The volume of the left and right hippocampus, thalamus, caudate nucleus, putamen, and cerebral hemispheres were quantified for all participants using the Cavalieri method of design-based stereology [21]. This approach has been frequently applied to MRI data in epilepsy studies [15, 22-24], has been considered the benchmark measurement approach to which automated MRI techniques have been compared ${ }^{[23]}$, and provides a mathematically unbiased and validated approach to estimate brain compartment volume ${ }^{[21,25]}$.

Using Easymeasure software ${ }^{[23]}$, each volume of interest (VOI) was estimated using a series of parallel two-dimensional (2D) MR sections set at a constant distance apart. A randomly orientated grid of pixels was overlaid on each section and points intersecting each region-of-interest (ROI) were counted separately for the left and right 
medRxiv preprint doi: https://doi.org/10.1101/2020.07.24.20159368; this version posted July 25, 2020. The copyright holder for this preprint (which was not certified by peer review) is the author/funder, who has granted medRxiv a license to display the preprint in perpetuity. It is made available under a CC-BY-ND 4.0 International license .

structures of each patient and control. The pixel size used for point-counting was altered depending on the size of the ROI (pixel sizes: hippocampus, 4; thalamus, 6; caudate nucleus, 5; putamen, 6; and cerebral hemisphere, 30) in order to optimise the sampling density ${ }^{[21]}$. The number of points transecting the ROI was multiplied by distance between each consecutive section to produce volume estimates. Given that nuclei (e.g. thalamic nuclei) and subregions (e.g. hippocampal cornu ammonis) of structures measured are almost indistinguishable on clinical MRI, we measured the structures as an entire complex.

Stereological point counting on MR images for volume estimation of the hippocampus, thalamus, caudate nucleus and putamen is shown in Figure 1. Detailed information on the hippocampal VOI is provided elsewhere ${ }^{[24]}$. Moving along its longitudinal axis, the hippocampus is bound superiorly by the white, myelinated fibres of the alveus and often by an additional region of cerebrospinal fluid superior to the alveus. The hippocampus was differentiated anteriorly from the amygdala through visualisation of the alveus. The posterior boundary of the hippocampus was reached when the lateral ventricles divide into the frontal and temporal horns. The hippocampal VOI comprised the hippocampus proper, dentate gyrus, alveus, subiculum, presubiculum and parasubiculum; the amygdala, uncus, choroid plexus and grey matter above the alveus were not included in the measurements. 

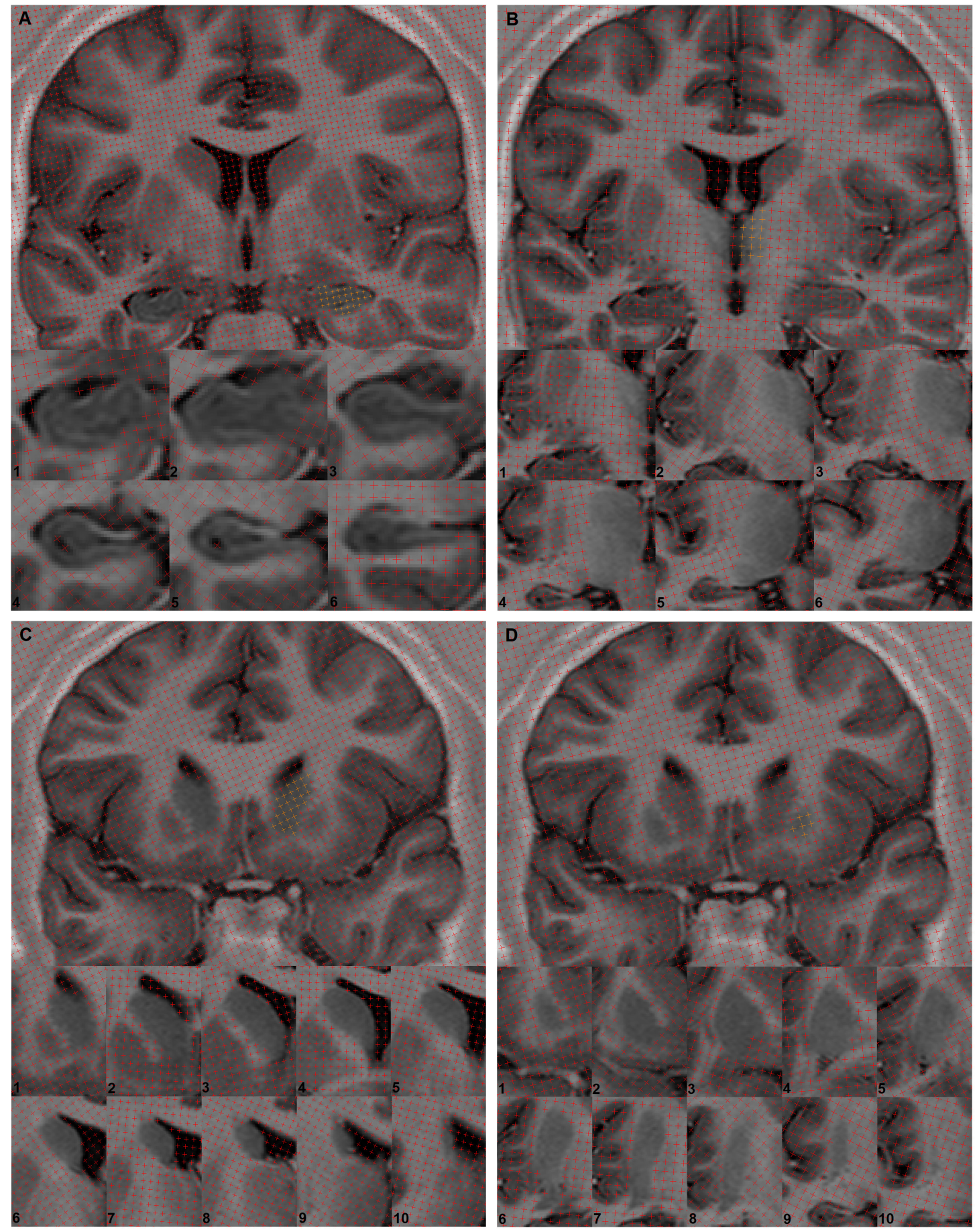

Figure 1. T1-weighted fluid attenuated inversion recovery coronal sections through an exemplar patient showing point counting for stereology through the subcortical volumes of interest. For each structure, point counts are removed in the left hemisphere and coloured orange in the right hemisphere. A, hippocampus; $B$, thalamus; $C$, caudate nucleus; $D$, putamen. Zoomed sections at the bottom of each panel show point counting in a rostral (top left) to caudal (bottom right) direction. 
medRxiv preprint doi: https://doi.org/10.1101/2020.07.24.20159368; this version posted July 25, 2020. The copyright holder for this preprint (which was not certified by peer review) is the author/funder, who has granted medRxiv a license to display the preprint in perpetuity.

It is made available under a CC-BY-ND 4.0 International license .

The anterior border of the thalamus began immediately posterior to the anterior commissure and maintained a close relationship with the internal capsule laterally and the central canal of the ventricles medially; the posterior border of the thalamus was the pulvinar. Measurements ended with the formation of the atrium of the ventricles. The zona incerta formed the inferior border of the thalamus. We excluded the subthalamic nuclei, substantia nigra, and red nuclei from thalamic measurements. The lateral and medial geniculate bodies and the habenular nucleus were also excluded [23]. The posterior border of the caudate nucleus was considered the last slide in which the caudate tail was still superior to the lateral ventricle. Caudate nucleus and putamen measurements ended with the formation of the atrium from the temporal and frontal horns of the lateral ventricle. Neither caudate nucleus nor putamen measurements included the striatal cell bridges connecting the two nuclei or the nucleus accumbens. The medial and lateral borders of the putamen were the internal capsule and external capsule, respectively ${ }^{[22]}$. The posterior border of the putamen often coincides with the appearance of the medial and lateral geniculate bodies. Measurement of the entire cerebral hemispheres was also obtained which included all supratentorial grey and white matter, excluding the brainstem and cerebellum. All subcortical and hemispheric volumes were normalised using whole brain volumes (summation of left and right cerebral hemispheric volumes); the proportion of each subcortical and hemispheric volume relative to whole brain volume was calculated.

\section{Statistical analysis}

The data did not meet the assumptions of parametric tests; therefore, nonparametric tests were used to analyse the data. For patient-control analysis, all volumes were analysed using nonparametric Mann-Whitney U-tests in SPSS (version 25, 
medRxiv preprint doi: https://doi.org/10.1101/2020.07.24.20159368; this version posted July 25, 2020. The copyright holder for this preprint (which was not certified by peer review) is the author/funder, who has granted medRxiv a license to display the preprint in perpetuity. It is made available under a CC-BY-ND 4.0 International license .

www.spss.com). Given the significant sex difference between patients and controls, and the higher average age of patients compared to controls, we performed all statistical analyses on normalised volumes, with their residuals corrected for age and sex in a confound only regression model. Volumes lower than two standard deviations of the control mean were considered abnormal and suggestive of structural atrophy in individual patients. Spearman's correlations were used to investigate relationships between volumes and age at first seizure, years between first seizure and diagnosis, and age at diagnosis. Categorical analysis of clinical and neuroimaging data was performed using Chi-squared tests. Multiple comparisons were corrected using the false discovery rate (FDR) and results were considered statistically significant at $P<$ 0.05 . 
medRxiv preprint doi: https://doi.org/10.1101/2020.07.24.20159368; this version posted July 25, 2020. The copyright holder for this preprint (which was not certified by peer review) is the author/funder, who has granted medRxiv a license to display the preprint in perpetuity.

\section{Results}

\section{Clinical data}

Two patients did not commence AED treatment. These patients did not have outcome data. For the remainder of the patient cohort, the first AED used was Lamotrigine $(n=$ 47, 59\%), Levetiracetam ( $n=14,18 \%)$, Zonisamide $(n=8,10 \%)$, Carbamazepine $(n$ $=6,8 \%)$, Sodium Valproate $(n=3,4 \%)$, Oxcarbazepine $(n=1,1 \%)$ and Phenytoin $(n$ $=1,1 \%)$. There were no significant associations in the clinical data.

\section{Volumetric changes in NDfE}

Volumetric descriptive statistics are provided in Table 2. Volume of the left hippocampus $\left(U=1232, P_{(\text {FDR-corr })}=0.04\right)$, and left $\left(U=1002, P_{(\text {FDR-corr })}=0.002\right)$ and right $\left(U=1228, P_{(\text {FDR-corr })}=0.04\right)$ thalamus were significantly smaller in patients compared to controls (Figure 2). There was a trend for the right hippocampus to be smaller in patients relative to controls $\left(U=1311, P_{\text {(FDR-corr })}=0.09\right)$. There were no significant differences $\left(P_{(\text {FDR-corr })}<0.05\right)$ or trends for differences in volume of the left or right caudate nucleus, putamen or whole cerebral hemisphere between patients and controls. In patients, average volume of the left hippocampus was decreased by $6.9 \%$, right hippocampus by $6.5 \%$, left thalamus by $6.4 \%$, and right thalamus by $4.1 \%$, relative to controls. Individual volumetric analysis revealed abnormal volume of the left hippocampus in 9 (11\%) patients, the right hippocampus in $4(4.9 \%)$ patients, the left thalamus in $14(17.1 \%)$ patients, and the right thalamus in $7(8.5 \%)$ patients. 
medRxiv preprint doi: https://doi.org/10.1101/2020.07.24.20159368; this version posted July 25, 2020. The copyright holder for this preprint (which was not certified by peer review) is the author/funder, who has granted medRxiv a license to display the preprint in perpetuity.

It is made available under a CC-BY-ND 4.0 International license .

\begin{tabular}{|c|c|c|c|c|c|c|c|}
\hline \multirow[b]{2}{*}{ Structure } & \multirow[b]{2}{*}{ Mean } & \multicolumn{2}{|c|}{ Patients } & \multicolumn{3}{|c|}{ Controls } & \multirow[b]{2}{*}{$U, P$ (FDRcorr) } \\
\hline & & SD & $\begin{array}{c}\text { Abnormal } \\
(n, \%)\end{array}$ & Mean & SD & $\begin{array}{c}\text { Abnormal } \\
(n, \%)\end{array}$ & \\
\hline \multicolumn{8}{|l|}{ Left hippocampus } \\
\hline (\%CorrAgeSex) & 0.190 & 0.033 & 9,11 & 0.204 & 0.025 & $1,2.5$ & $U=1232, P=0.04$ \\
\hline$\left(\mathrm{cm}^{3}\right)$ & 2.075 & 0.427 & $19,23.2$ & 2.270 & 0.233 & 0 & - \\
\hline \multicolumn{8}{|l|}{ Right hippocampus } \\
\hline (\%CorrAgeSex) & 0.188 & 0.034 & $4,4.9$ & 0.201 & 0.031 & 0 & $U=1311, P=0.09$ \\
\hline$\left(\mathrm{cm}^{3}\right)$ & 2.058 & 0.450 & $10,12.2$ & 2.221 & 0.292 & $1,2.5$ & - \\
\hline \multicolumn{8}{|l|}{ Left thalamus } \\
\hline (\%CorrAgeSex) & 0.642 & 0.068 & $14,17.1$ & 0.686 & 0.055 & $1,2.5$ & $U=1002, P=0.002$ \\
\hline$\left(\mathrm{cm}^{3}\right)$ & 7.021 & 0.915 & $6,7.3$ & 7.609 & 0.934 & 0 & - \\
\hline \multicolumn{8}{|l|}{ Right thalamus } \\
\hline (\%CorrAgeSex) & 0.638 & 0.069 & $7,8.5$ & 0.665 & 0.062 & $1,2.5$ & $U=1228, P=0.04$ \\
\hline$\left(\mathrm{cm}^{3}\right)$ & 6.986 & 0.938 & $6,7.3$ & 7.362 & 0.934 & 0 & - \\
\hline \multicolumn{8}{|l|}{ Left caudate } \\
\hline (\%CorrAgeSex) & 0.371 & 0.054 & $5,6.1$ & 0.368 & 0.040 & $1,2.5$ & $U=1621, P=0.46$ \\
\hline$\left(\mathrm{cm}^{3}\right)$ & 4.054 & 0.634 & $3,3.7$ & 4.063 & 0.487 & 0 & - \\
\hline \multicolumn{8}{|l|}{ Right caudate } \\
\hline (\%CorrAgeSex) & 0.363 & 0.050 & 0 & 0.355 & 0.044 & $1,2.5$ & $U=1513, P=0.39$ \\
\hline$\left(\mathrm{cm}^{3}\right)$ & 3.963 & 0.579 & $2,2.4$ & 3.932 & 0.509 & 0 & - \\
\hline \multicolumn{8}{|l|}{ Left putamen } \\
\hline (\%CorrAgeSex) & 0.467 & 0.051 & $3,3.7$ & 0.464 & 0.043 & 0 & $U=1623, P=0.46$ \\
\hline$\left(\mathrm{cm}^{3}\right)$ & 5.091 & 0.493 & $1,1.2$ & 5.111 & 0.474 & 0 & - \\
\hline \multicolumn{8}{|l|}{ Right putamen } \\
\hline (\%CorrAgeSex) & 0.473 & 0.053 & $2,2.4$ & 0.469 & 0.044 & 0 & $U=1545, P=0.39$ \\
\hline$\left(\mathrm{cm}^{3}\right)$ & 5.164 & 0.539 & 0 & 5.176 & 0.551 & $1,2.5$ & - \\
\hline \multicolumn{8}{|l|}{ Left hemisphere } \\
\hline (\%CorrAgeSex) & 49.98 & 0.66 & $5,6.1$ & 49.95 & 0.50 & 0 & $U=1550, P=0.39$ \\
\hline$\left(\mathrm{cm}^{3}\right)$ & 550.3 & 56.7 & $1,1.2$ & 549.5 & 52.5 & 0 & - \\
\hline \multicolumn{8}{|l|}{ Right hemisphere } \\
\hline (\%CorrAgeSex) & 50.02 & 0.66 & $4,4.9$ & 50.05 & 0.50 & 0 & $U=1550, P=0.39$ \\
\hline$\left(\mathrm{cm}^{3}\right)$ & 550.2 & 56.5 & $1,1.2$ & 551.4 & 51.3 & 0 & - \\
\hline
\end{tabular}

Table 2. Results of volumetric comparisons between patients and controls. Mean and standard deviation (SD) of subcortical and hemispheric volumes, expressed as percentage of whole brain volume and their residuals corrected for age and sex (\%CorrAgeSex), and raw volume $\left(\mathrm{cm}^{3}\right)$. For each structure the number (and percentage) of patients with volumes lower than the normal limits is indicated as abnormal $(n, \%)$. 


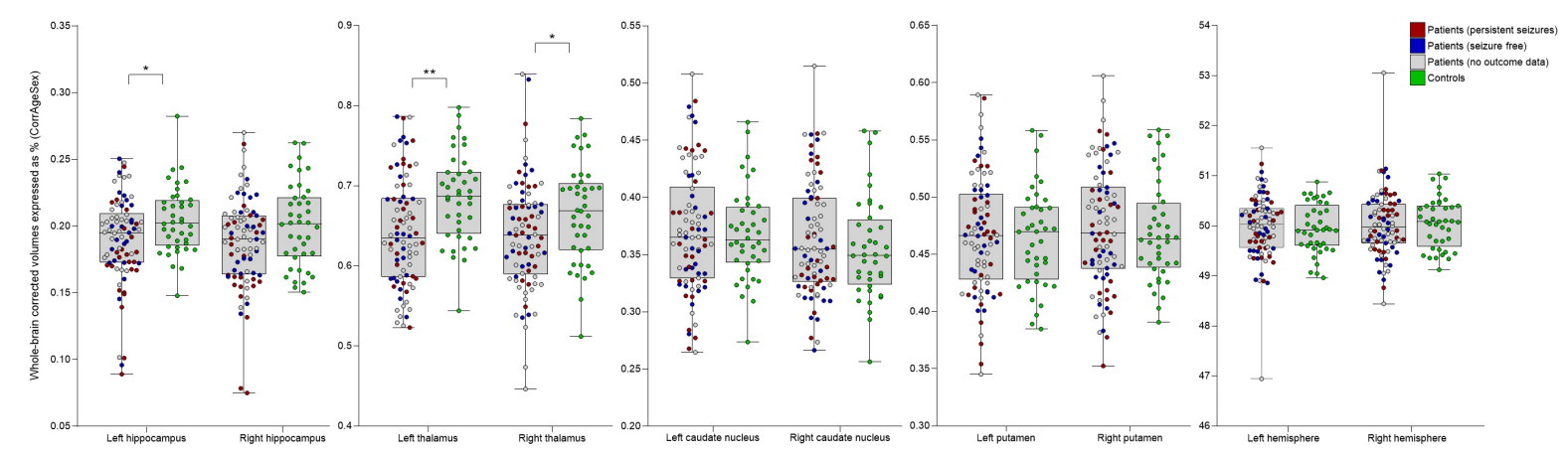

Figure 2. Scatterplots with minimum, 25th percentile, median, 75th percentile, and maximum normalised and corrected volume measurements of brain structures in seizure free patients, patients with persistent seizures, and healthy controls. Statistically significant between groups: ${ }^{*}\left(P_{(\text {FDRcorr })}<0.05\right),{ }^{* *}\left(P_{(\text {FDRcorr })}<0.01\right)$.

\section{Correlations with clinical variables}

There were no associations between volumes and seizure outcome at 6 or 12 months, EEG finding, loss of awareness during seizures, history of FBTCS, age at first seizure, years between first seizure and diagnosis or age at diagnosis. Table 3 presents the descriptive and statistical comparisons between outcome groups at 12 months. There were also no clinically significant differences between the individual patients who had significant loss of hippocampal and thalamic volume and those who did not. 
medRxiv preprint doi: https://doi.org/10.1101/2020.07.24.20159368; this version posted July 25, 2020. The copyright holder for this preprint (which was not certified by peer review) is the author/funder, who has granted medRxiv a license to display the preprint in perpetuity.

It is made available under a CC-BY-ND 4.0 International license .

\begin{tabular}{|c|c|c|c|c|c|}
\hline \multirow{2}{*}{$\begin{array}{l}\text { Structure } \\
n(\%)\end{array}$} & \multicolumn{2}{|c|}{ Seizure free } & \multicolumn{2}{|c|}{ Persistent seizures } & \multirow{2}{*}{$\begin{array}{l}x^{2}, U, P(\text { FDRcorr }) \\
-\end{array}$} \\
\hline & $24(50)$ & & $24(50)$ & & \\
\hline Male / female & $14(58.3)$ & $10(41.7)$ & $14(58.3)$ & $10(41.7)$ & $x^{2}=0, P=1.0$ \\
\hline FAS / FIAS & $11(45.8)$ & $13(54.2)$ & $7(29.2)$ & $17(70.8)$ & $x^{2}=1.42, P=0.49$ \\
\hline FTBS / no FTBS + & $22(91.7)$ & $2(8.3)$ & $18(75)$ & $5(20.8)$ & $x^{2}=1.67, P=0.49$ \\
\hline Normal / abnormal EEG‡ & $11(45.8)$ & $2(8.3)$ & $7(29.2)$ & $7(29.2)$ & $x^{2}=3.64, P=0.41$ \\
\hline \multicolumn{6}{|l|}{ Mean / SD } \\
\hline Age & 39.71 & 12.22 & 37.00 & 10.25 & $U=251, P=0.45$ \\
\hline Age of onset & 32.21 & 12.33 & 29.33 & 11.01 & $U=250, P=0.45$ \\
\hline \multicolumn{6}{|l|}{ Left hippocampus } \\
\hline (\%CorrAgeSex) & 0.193 & 0.032 & 0.175 & 0.035 & $U=185, P=0.34$ \\
\hline$\left(\mathrm{cm}^{3}\right)$ & 2.101 & 0.369 & 1.926 & 0.507 & - \\
\hline \multicolumn{6}{|l|}{ Right hippocampus } \\
\hline (\%CorrAgeSex) & 0.189 & 0.028 & 0.172 & 0.041 & $U=201, P=0.37$ \\
\hline$\left(\mathrm{cm}^{3}\right)$ & 2.070 & 0.336 & 1.892 & 0.520 & - \\
\hline \multicolumn{6}{|l|}{ Left thalamus } \\
\hline (\%CorrAgeSex) & 0.651 & 0.071 & 0.653 & 0.068 & $U=280, P=0.98$ \\
\hline$\left(\mathrm{cm}^{3}\right)$ & 7.156 & 0.906 & 7.157 & 0.917 & - \\
\hline \multicolumn{6}{|l|}{ Right thalamus } \\
\hline (\%CorrAgeSex) & 0.654 & 0.064 & 0.646 & 0.051 & $U=257, P=0.98$ \\
\hline$\left(\mathrm{cm}^{3}\right)$ & 7.209 & 0.923 & 7.084 & 0.792 & - \\
\hline \multicolumn{6}{|l|}{ Left caudate } \\
\hline (\%CorrAgeSex) & 0.367 & 0.053 & 0.365 & 0.058 & $U=288, P=1.0$ \\
\hline$\left(\mathrm{cm}^{3}\right)$ & 4.038 & 0.647 & 3.982 & 0.577 & - \\
\hline \multicolumn{6}{|l|}{ Right caudate } \\
\hline (\%CorrAgeSex) & 0.355 & 0.052 & 0.363 & 0.051 & $U=255, P=0.98$ \\
\hline$\left(\mathrm{cm}^{3}\right)$ & 3.894 & 0.614 & 3.963 & 0.503 & - \\
\hline \multicolumn{6}{|l|}{ Left putamen } \\
\hline (\%CorrAgeSex) & 0.468 & 0.045 & 0.462 & 0.055 & $U=276, P=0.98$ \\
\hline$\left(\mathrm{cm}^{3}\right)$ & 5.134 & 0.367 & 5.059 & 0.618 & - \\
\hline \multicolumn{6}{|l|}{ Right putamen } \\
\hline (\%CorrAgeSex) & 0.469 & 0.047 & 0.461 & 0.054 & $U=271, P=0.98$ \\
\hline$\left(\mathrm{cm}^{3}\right)$ & 5.150 & 0.528 & 5.042 & 0.571 & - \\
\hline \multicolumn{6}{|l|}{ Left hemisphere } \\
\hline (\%CorrAgeSex) & 50.00 & 0.63 & 49.94 & 0.54 & $U=264, P=0.98$ \\
\hline$\left(\mathrm{cm}^{3}\right)$ & 553.7 & 56.2 & 549.7 & 56.7 & - \\
\hline \multicolumn{6}{|l|}{ Right hemisphere } \\
\hline (\%CorrAgeSex) & 50.00 & 0.63 & 50.06 & 0.54 & $U=264, P=0.98$ \\
\hline$\left(\mathrm{cm}^{3}\right)$ & 553.1 & 55.4 & 550.8 & 56.6 & - \\
\hline
\end{tabular}

Table 3. Results of clinical and volumetric comparisons between seizure free patients and patients with persistent seizures at 12 months. FAS, focal aware seizures; FIAS, focal impaired awareness seizures; FBTCS, focal to bilateral tonic-clonic seizures; EEG, electroencephalography.

†FBTCS data not available for one patient with persistent seizures.

łEEG data not available for $11(45.8 \%)$ seizure free patients and $10(41.7 \%)$ patients with persistent seizures. 
medRxiv preprint doi: https://doi.org/10.1101/2020.07.24.20159368; this version posted July 25, 2020. The copyright holder for this preprint (which was not certified by peer review) is the author/funder, who has granted medRxiv a license to display the preprint in perpetuity.

\section{Discussion}

In the present study we sought to establish whether structures that are known to show atrophy in focal epilepsy also show evidence of volume loss at the time of diagnosis of epilepsy. We report significant volume loss of the thalamus and hippocampus in adults with NDfE. Additionally, we aimed to explore whether clinical variables were associated with volume changes. Atrophy of subcortical structures was not related to seizure outcome at either 6 or 12 months or any other clinical characteristic of epilepsy.

\section{Biological and clinical implications}

Of the limited number of quantitative MRI studies that exist in NDfE, the focus has been on the hippocampus. Our results are in support of those studies that reported hippocampal atrophy at diagnosis ${ }^{[14,15,26]}$ and are in contrast to those that did not report atrophy ${ }^{[16]}$. Patients with chronic epilepsy have shown a 13 to $16 \%$ reduction in hippocampal volume compared to controls [26]; we identified a 6.5 to $6.9 \%$ decrease in hippocampal volume which may indicate hippocampal atrophy is present at time of diagnosis and may worsen with the progression of epilepsy. The present study also sought to determine whether extrahippocampal subcortical atrophy was present at diagnosis. To our knowledge, the present study is the first to identify thalamic atrophy in adults with a new diagnosis of focal epilepsy. A previous study in a small sample of patients with NDfE did not report thalamic atrophy ${ }^{[16]}$. Thalamic atrophy has been reported to be almost as common as hippocampal atrophy in a meta-analysis of voxelbased morphometry studies of refractory TLE ${ }^{[27]}$, and is observed in a range of longstanding focal and generalised epilepsy disorders ${ }^{[2,28]}$. Thalamic volume loss has also been reported in children with NDfE ${ }^{[29]}$ and patients with new-onset GGE [19]. Consistent with our findings, volume loss of the thalamus in both hemispheres is 
medRxiv preprint doi: https://doi.org/10.1101/2020.07.24.20159368; this version posted July 25, 2020. The copyright holder for this preprint (which was not certified by peer review) is the author/funder, who has granted medRxiv a license to display the preprint in perpetuity.

It is made available under a CC-BY-ND 4.0 International license .

frequently reported in patients with chronic focal epilepsy [2, 28, 30-32]. Taken together, our results suggest that thalamohippocampal atrophy is likely established prior to the onset of habitual epilepsy; further hippocampal and thalamic damage may occur as the disorder becomes longstanding, particularly in refractory cases ${ }^{[33-35]}$.

There are very few existing studies that have attempted to predict pharmacoresistance from the point of diagnosis of focal epilepsy using advanced imaging in a way that resembles work predicting surgical outcome in focal epilepsy ${ }^{[31,36]}$. This is an unmet need in the early stages of the disorder $[7,8,37]$. Having a reliable imaging biomarker of the health issues patients will experience (e.g. uncontrolled seizures, memory impairment) from diagnosis will provide clinicians and patients with realistic expectations and could serve to assist the patient management pathway (e.g. earlier use of adjunctive / alternative therapies in patients likely to be pharmacoresistant) [37]. In the present study we have reported that gross neuroanatomical volume of subcortical structures are not related to seizure control at 6 or 12 months after diagnosis. (We note the relatively brief follow up; however, 12-month outcome is highly predictive of pharmacoresistance in NDE ${ }^{[12]}$.) The advantage of investigating potential imaging biomarkers using MRI acquired as part of standard diagnostic evaluation is the applicability of findings to routine clinical practice. However, the disadvantage is that highly variable gross brain morphology is unlikely to be sensitive enough to identify markers of pharmacoresistance. It is likely that these markers, if found, will be microstructural, functional, or metabolic. Interestingly, in patients with longstanding focal epilepsy, MR spectroscopy hippocampal N-Acetylaspartate/Creatine measurements have been related to seizure control ${ }^{[38]}$. 
medRxiv preprint doi: https://doi.org/10.1101/2020.07.24.20159368; this version posted July 25, 2020. The copyright holder for this preprint (which was not certified by peer review) is the author/funder, who has granted medRxiv a license to display the preprint in perpetuity.

It is made available under a CC-BY-ND 4.0 International license .

Approximately $50 \%$ of patients with NDfE exhibit impairment in at least one cognitive domain ${ }^{[13]}$. Although we did not assess cognition in the current study, atrophy of subcortical structures may be related to cognitive impairment in patients with NDfE. Previous research has shown hippocampal volume loss is associated with poorer verbal memory performance in NDfE ${ }^{[14]}$ and higher seizure frequency after AED withdrawal in TLE ${ }^{[39]}$. Lower thalamic volume and higher seizure frequency have been observed in cognitively impaired children with NDE ${ }^{[29]}$. Future research of imaging and cognitive biomarkers of pharmacoresistance in NDfE would be beneficial in establishing the most effective treatment pathways for patients likely to experience refractory epilepsy ${ }^{[37]}$.

\section{Methodological issues}

The discrepancy between our findings and those of a previous study that did not report thalamic atrophy in patients with NDfE ${ }^{[16]}$ is difficult to reconcile. We have previously demonstrated good agreement between stereology and Freesurfer analysis - the method used by the previous study - for volume estimation of the thalamus [23]; therefore image analysis approach is unlikely to be a factor. The substantially larger sample size of the present study is also unlikely to explain this discrepancy as the previous study reported a small trend for increased thalamic volume in patients with NDfE [16]. Both studies investigated only patients with non-lesional NDfE. The only remaining difference between studies is type of MRI scans. The previous study used conventional three-dimensional (3D) T1-weighted scans with isotropic voxels (1 $\mathrm{mm} \mathrm{x}$ $1 \mathrm{~mm} \times 1 \mathrm{~mm}$ ), which offers limited differentiation between thalamic grey matter and adjacent white matter ${ }^{[23]}$. We used non-isotropic T1-weighted FLAIR with high 
medRxiv preprint doi: https://doi.org/10.1101/2020.07.24.20159368; this version posted July 25, 2020. The copyright holder for this preprint (which was not certified by peer review) is the author/funder, who has granted medRxiv a license to display the preprint in perpetuity. It is made available under a CC-BY-ND 4.0 International license .

resolution in-plane coronal sections $(0.4 \mathrm{~mm} \times 0.4 \mathrm{~mm})$, which provides superior delineation between the thalamus and white matter (Figure 1).

The standard MRI protocol for patients with a new presentation of seizures at our institution does not include 3D volume scans that would be amenable to automated segmentation techniques. It was necessary for us to apply manual volumetric analysis due to the $3 \mathrm{~mm}$ slice thickness of the coronal 2D T1-weighted FLAIR MRI scans. Despite this being a time-inefficient way of obtaining morphometric data, there were distinct advantages to our approach. Firstly, manual measurement of brain regions is considered gold standard and stereology provides a mathematically unbiased and validated approach to estimate brain compartment volume ${ }^{[21,25]}$. Secondly, despite the non-isotropic voxel size, the high in-plane resolution and contrast of the scans provided excellent grey-white matter differentiation, even in regions where the grey matter and white matter borders are difficult to establish (e.g. the thalamus).

Following diagnostic MRI most patients with NDfE will not undergo further investigation, which is usually undertaken in those with a refractory course, for who more precise localisation of the seizure focus is more likely as more seizures are witnessed and following increasingly detailed imaging, EEG and neuropsychological evaluation. Our sample of patients with NDfE is therefore likely to be clinically heterogenous in terms of seizure foci, despite commonalities in a new diagnosis of focal epilepsy and non-lesional MRI. We suggest that what is lost through the inclusion of a highly phenotyped group of patients is gained through a pragmatic approach to studying all non-lesional patients with a new diagnosis of focal epilepsy. Indeed, studying patients with NDfE pragmatically may yield common brain abnormalities, and 
medRxiv preprint doi: https://doi.org/10.1101/2020.07.24.20159368; this version posted July 25,2020 . The copyright holder for this preprint (which was not certified by peer review) is the author/funder, who has granted medRxiv a license to display the preprint in perpetuity.

It is made available under a CC-BY-ND 4.0 International license .

potentially biomarkers of treatment outcome, given that; (i) widespread alterations in brain network structure can give rise to a clearly localised focal onset in one brain region [40]; (ii) particular anatomical circuits act as critical modulators of seizure generation and propagation, and seizure activity does not spread diffusely throughout the brain but propagates along specific anatomical pathways, regardless of the localisation of the brain insult [41,42]; (iii) pathological structural connectivity causes disturbances to common large scale functional brain networks regardless of the localisation of the epileptogenic zone in patients with refractory focal epilepsy [43]; and (iv) subcortical structures - such as the thalamus and striatum - that play a crucial role in the clinical manifestation of seizures in the epilepsies ${ }^{[44]}$, and anatomically support widespread distributed cortico-subcortical networks [45], are structurally and physiologically abnormal in both hemispheres in patients with longstanding focal and generalised epilepsy disorders ${ }^{[2,28,44]}$.

\section{Conclusions}

Many specialist institutions and research centres do not see patients with epilepsy until it is well established, which may contribute to the lack of imaging studies of NDfE. In the present imaging study, we have studied a comparatively large number of patients with NDfE and report that atrophy of the hippocampi and thalami - ordinarily reported to be atrophic in longstanding and refractory focal epilepsy - is established at the time of diagnosis. It remains uncertain as to whether this atrophy is congenital, a consequence of epileptogenic processes or a combination of both. 
medRxiv preprint doi: https://doi.org/10.1101/2020.07.24.20159368; this version posted July 25,2020 . The copyright holder for this preprint (which was not certified by peer review) is the author/funder, who has granted medRxiv a license to display the preprint in perpetuity. It is made available under a CC-BY-ND 4.0 International license.

\section{Acknowledgements}

This work was funded by UK Medical Research Council (MR/S00355X/1 and MR/K023152/1) and Epilepsy Research UK (grant number 1085) grants awarded to SSK.

\section{Disclosure of conflicts of interest}

None of the authors has any conflict of interest to disclose. 
medRxiv preprint doi: https://doi.org/10.1101/2020.07.24.20159368; this version posted July 25 , 2020. The copyright holder for this preprint (which was not certified by peer review) is the author/funder, who has granted medRxiv a license to display the preprint in perpetuity. It is made available under a CC-BY-ND 4.0 International license.

\section{References}

[1]. Bonilha L, Keller SS. Quantitative MRI in refractory temporal lobe epilepsy: relationship with surgical outcomes. Quant Imaging Med Surg. 2015 5: 204-224.

[2]. Whelan CD, Altmann A, Botia JA, et al. Structural brain abnormalities in the common epilepsies assessed in a worldwide ENIGMA study. Brain. 2018 141: 391-408.

[3]. Reyes-Garcia SZ, Scorza CA, Araujo NS, et al. Different patterns of epileptiform-like activity are generated in the sclerotic hippocampus from patients with drug-resistant temporal lobe epilepsy. Sci Rep. 2018 8: 7116.

[4]. Guye M, Regis J, Tamura M, et al. The role of corticothalamic coupling in human temporal lobe epilepsy. Brain. 2006 129: 1917-1928.

[5]. Vuong J, Devergnas A. The role of the basal ganglia in the control of seizure. J Neural Transm (Vienna). 2018 125: 531-545.

[6]. Velisek L, Moshe SL. Temporal lobe epileptogenesis and epilepsy in the developing brain: bridging the gap between the laboratory and the clinic. Progression, but in what direction? Epilepsia. 200344 Suppl 12: 51-59.

[7]. Pohlmann-Eden B. Conceptual relevance of new-onset epilepsy. Epilepsia. 201152 Suppl 4: 1-6.

[8]. Pohlmann-Eden B, Crocker CE, Schmidt MH. A conceptual framework for the use of neuroimaging to study and predict pharmacoresistance in epilepsy. Epilepsia. 201354 Suppl 2: 75-79.

[9]. Pohlmann-Eden B, Aldenkamp A, Baker GA, et al. The relevance of neuropsychiatric symptoms and cognitive problems in new-onset epilepsy - Current knowledge and understanding. Epilepsy Behav. 2015 51: 199-209.

[10]. Brodie MJ. Road to refractory epilepsy: the Glasgow story. Epilepsia. 201354 Suppl 2: 5-8.

[11]. Bonnett L, Smith CT, Smith D, Williamson P, Chadwick D, Marson AG. Prognostic factors for time to treatment failure and time to 12 months of remission for patients with focal epilepsy: post-hoc, subgroup analyses of data from the SANAD trial. Lancet Neurol. 2012 11: 331-340.

[12]. Mohanraj R, Brodie MJ. Early predictors of outcome in newly diagnosed epilepsy. Seizure. 2013 22: 333-344.

[13]. Taylor J, Kolamunnage-Dona R, Marson AG, et al. Patients with epilepsy: cognitively compromised before the start of antiepileptic drug treatment? Epilepsia. 2010 51: 48-56.

[14]. Kalviainen R, Partanen K, Aikia M, et al. MRI-based hippocampal volumetry and T2 relaxometry: correlation to verbal memory performance in newly diagnosed epilepsy patients with left-sided temporal lobe focus. Neurology. 1997 48: 286-287.

[15]. Salmenpera T, Kononen M, Roberts N, Vanninen R, Pitkanen A, Kalviainen R. Hippocampal damage in newly diagnosed focal epilepsy: a prospective MRI study. Neurology. 2005 64: 62-68.

[16]. Park KM, Han YH, Kim TH, et al. Cerebellar white matter changes in patients with newly diagnosed partial epilepsy of unknown etiology. Clin Neurol Neurosurg. 2015 138: 2530.

[17]. Hagemann G, Lemieux L, Free SL, et al. Cerebellar volumes in newly diagnosed and chronic epilepsy. J Neurol. 2002 249: 1651-1658.

[18]. Alonazi BK, Keller SS, Fallon N, et al. Resting-state functional brain networks in adults with a new diagnosis of focal epilepsy. Brain Behav. 2018: e01168. 
medRxiv preprint doi: https://doi.org/10.1101/2020.07.24.20159368; this version posted July 25,2020 . The copyright holder for this preprint (which was not certified by peer review) is the author/funder, who has granted medRxiv a license to display the preprint in perpetuity. It is made available under a CC-BY-ND 4.0 International license.

[19]. Perani S, Tierney TM, Centeno $M$, et al. Thalamic volume reduction in drug-naive patients with new-onset genetic generalized epilepsy. Epilepsia. 2018 59: 226-234.

[20]. Kreilkamp BAK, Lisanti L, Glenn GR, et al. Comparison of manual and automated fiber quantification tractography in patients with temporal lobe epilepsy. Neuroimage Clin. 2019 24: 102024.

[21]. Roberts N, Puddephat MJ, McNulty V. The benefit of stereology for quantitative radiology. Br J Radiol. 2000 73: 679-697.

[22]. Keller SS, Ahrens T, Mohammadi S, et al. Microstructural and volumetric abnormalities of the putamen in juvenile myoclonic epilepsy. Epilepsia. 2011 52: 1715-1724. [23]. Keller SS, Gerdes JS, Mohammadi S, et al. Volume estimation of the thalamus using freesurfer and stereology: consistency between methods. Neuroinformatics. 2012 10: 341350.

[24]. Keller SS, Mackay CE, Barrick TR, Wieshmann UC, Howard MA, Roberts N. Voxelbased morphometric comparison of hippocampal and extrahippocampal abnormalities in patients with left and right hippocampal atrophy. Neuroimage. 2002 16: 23-31.

[25]. Doherty CP, Fitzsimons M, Holohan T, et al. Accuracy and validity of stereology as a quantitative method for assessment of human temporal lobe volumes acquired by magnetic resonance imaging. Magn Reson Imaging. 2000 18: 1017-1025.

[26]. Saukkonen A, Kalviainen R, Partanen K, Vainio P, Riekkinen P, Pitkanen A. Do seizures cause neuronal damage? A MRI study in newly diagnosed and chronic epilepsy. Neuroreport. 1994 6: 219-223.

[27]. Barron DS, Fox PM, Laird AR, Robinson JL, Fox PT. Thalamic medial dorsal nucleus atrophy in medial temporal lobe epilepsy: A VBM meta-analysis. Neuroimage Clin. 2012 2: 25-32.

[28]. Keller SS, Roberts N. Voxel-based morphometry of temporal lobe epilepsy: an introduction and review of the literature. Epilepsia. 2008 49: 741-757.

[29]. Yoong M, Hunter M, Stephen J, et al. Cognitive impairment in early onset epilepsy is associated with reduced left thalamic volume. Epilepsy Behav. 2018 80: 266-271.

[30]. Keller SS, Richardson MP, O'Muircheartaigh J, Schoene-Bake JC, Elger C, Weber B. Morphometric MRI alterations and postoperative seizure control in refractory temporal lobe epilepsy. Hum Brain Mapp. 2015 36: 1637-1647.

[31]. Keller SS, Richardson MP, Schoene-Bake JC, et al. Thalamotemporal alteration and postoperative seizures in temporal lobe epilepsy. Ann Neurol. 2015 77: 760-774.

[32]. Szabo CA, Lancaster JL, Lee S, et al. MR imaging volumetry of subcortical structures and cerebellar hemispheres in temporal lobe epilepsy. AJNR Am J Neuroradiol. 2006 27:

2155-2160.

[33]. Keller SS, Wieshmann UC, Mackay CE, Denby CE, Webb J, Roberts N. Voxel based morphometry of grey matter abnormalities in patients with medically intractable temporal lobe epilepsy: effects of side of seizure onset and epilepsy duration. J Neurol Neurosurg Psychiatry. 2002 73: 648-655.

[34]. Kalviainen R, Salmenpera T. Do recurrent seizures cause neuronal damage? A series of studies with MRI volumetry in adults with partial epilepsy. Prog Brain Res. 2002 135: 279295.

[35]. Kalviainen R, Salmenpera T, Partanen K, Vainio P, Riekkinen P, Pitkanen A. Recurrent seizures may cause hippocampal damage in temporal lobe epilepsy. Neurology. 1998 50:

1377-1382. 
medRxiv preprint doi: https://doi.org/10.1101/2020.07.24.20159368; this version posted July 25, 2020. The copyright holder for this preprint (which was not certified by peer review) is the author/funder, who has granted medRxiv a license to display the preprint in perpetuity. It is made available under a CC-BY-ND 4.0 International license .

[36]. Bonilha L, Jensen JH, Baker N, et al. The brain connectome as a personalized biomarker of seizure outcomes after temporal lobectomy. Neurology. 2015 84: 1846-1853. [37]. de Bezenac C, Garcia-Finana M, Baker G, et al. Investigating imaging network markers of cognitive dysfunction and pharmacoresistance in newly diagnosed epilepsy: a protocol for an observational cohort study in the UK. BMJ Open. 2019 9: e034347.

[38]. Campos BA, Yasuda CL, Castellano G, Bilevicius E, Li LM, Cendes F. Proton MRS may predict AED response in patients with TLE. Epilepsia. 2010 51: 783-788.

[39]. Cardoso TA, Coan AC, Kobayashi E, Guerreiro CA, Li LM, Cendes F. Hippocampal abnormalities and seizure recurrence after antiepileptic drug withdrawal. Neurology. 2006 67: 134-136.

[40]. Terry JR, Benjamin O, Richardson MP. Seizure generation: The role of nodes and networks. Epilepsia. 2012 53: e166-169.

[41]. Loscher W, Ebert U. The role of the piriform cortex in kindling. Prog Neurobiol. 1996 50: 427-481.

[42]. Piredda S, Gale K. A crucial epileptogenic site in the deep prepiriform cortex. Nature. 1985 317: 623-625.

[43]. Besson P, Bandt SK, Proix T, et al. Anatomic consistencies across epilepsies: a stereotactic-EEG informed high-resolution structural connectivity study. Brain. 2017 140: 2639-2652.

[44]. Dreifuss S, Vingerhoets FJ, Lazeyras F, et al. Volumetric measurements of subcortical nuclei in patients with temporal lobe epilepsy. Neurology. 2001 57: 1636-1641.

[45]. Nieuwenhuys R, Voogd J, van Huijzen C. The human central nervous system. 3rd ed edn. New York: Springer-Verlag, 1988. 